\title{
Assesment of Optic Nerve Sheath Diameter in Healthy Adults in Turkey
}

\author{
Türkiye’de Sağlıklı Erişkinlerde Optik Sinir Kılıfı Çapının Değerlendirilmesi
}

\author{
Emre Gökçen ${ }^{1}$, İbrahim Çaltekin ${ }^{1}$, Levent Albayrak ${ }^{1}$, Atakan Savrun ${ }^{2}$, Dilek Atik ${ }^{1}$, \\ Sevilay Vural ${ }^{1}$, Nuray Kılıç ${ }^{1}$, Mikail Kuşdoğan ${ }^{1}$, Hasan Burak Kaya ${ }^{1}$ \\ ${ }^{1}$ Acil Tip Anabilim Dal, Bozok Üniversitesi Tip Fakültesi \\ ${ }^{2}$ Acil Tip Anabilim Dalı, Ordu Üniversitesi Tip Fakültesi \\ Yazışma Adresi / Correspondence: \\ Emre Gökçen \\ Yozgat Bozok Üniversitesi, Erdoğan Akdağ Yerleşkesi, Atatürk yolu 7. Km, Merkez-Yozgat /Türkiye \\ T: +90505 5718688 E-mail : emregokcenacl@gmail.com \\ Geliş Tarihi / Received : 29.08.2020 Kabul Tarihi / Accepted : 05.01.2021
}

Orcid :

Emre Gökçen https://orcid.org/0000-0002-6018-6105 Hasan Burak Kaya https://orcid.org/0000-0001-8851-2614 İbrahim Çaltekin https://orcid.org/0000-0002-3973-0655 Levent Albayrak https://orcid.org/0000-0002-4288-8170 Atakan Savrun https://orcid.org/0000-0001-7468-4159
Mikail Kuşdoğan https://orcid.org/0000-0003-4075-8601 Nuray Kılıç https://orcid.org/0000-0003-1371-3600 Sevilay Vural https://orcid.org/0000-0002-1722-7987 Dilek Atik https://orcid.org/0000-0002-3270-8711

( Sakarya Tip Dergisi / Sakarya Med J 2021, 11(1):85-90 ) DOI: 10.31832 smj.787427

\footnotetext{
Abstract

Objective The ultrasonographically detected optic nerve sheath diameter (ONSD) measurement is a practical and non-invasive method for the detection of increased intracranial pressure. However, it is important to know the normal ONSD values of a healthy population in the interpretation of pathological ONSD values. In this study, we aimed to investigate how the normal values of ONSD are distributed in normal healthy volunteers in Turkish population.

Materials This descriptive cross sectional type design study was planned between November 15, 2019 and April 15, 2020. The study included 160 healthy volunteers who were over 18 and Methods years of age and didn't have acute and chronic systemic disorders. ONSD of the subjects were measured from both eyes ultrasonographically.

Results ONSD means (median, IQR) of right and left eyes of the subjects were measured as $4.87(0.41) \mathrm{mm}$ and $4.86(0.32) \mathrm{mm}$, respectively. Right and left eye ONSD measurements were detected lower in female gender than men, and this difference was statistically significant. ( $\mathrm{p}=0.017$ and $\mathrm{p}=0.031$, respectively).

Conclusion It was found ONSD value as 4.87 (0.41) for the right eye and $4.86(0.32) \mathrm{mm}$ for the left eye in healthy individuals in Turkish population in our study. Determination of ONSD optimal reference values in healthy individuals would benefit in predicting increase in intracranial pressure in clinical practice.

Keywords optic nerve sheath diameter; ultrasonography; healthy volunteer

Öz

Amaç Artmış intrakranial basınç artıșının tespitinde ultrasonografik olarak tespit edilen optik sinir killf çapı (OSKÇ) ölçümü pratik ve non invaziv bir yöntemdir. Bununla birlikte patolojik OSKÇ değerlerinin yorumlanmasında sağllklı bir popülasyonun normal OSKC değerlerinin bilinmesi önem arz eder. Biz bu çalsșmada Türk popülasyonundaki normal sağlkkl gönüllülerde OSKC normal değerlerinin nasıl dağıldı̆̆ıı araștırmak istedik.

Gereçve Bu kesitsel tipte tanımlayıcı araștırma, 15 Kastm 2019 ile 15 Nisan 2020 tarihleri arasında planlandı. Çalıșmaya 18 yaș üstü, akut ve kronik sistemik rahatsızly̆g bulunmayan 160 sağlkklı Yöntemler gönüllü dahil edildi. Deneklerin her iki gözden ultrasonografik olarak OSKÇ’ları ölçüldü.

Bulgular Deneklerin sağ ve sol göz OSKÇ ortalamaları (median, IQR) strasıly 4,87 (0,41) mm ve 4,86 $(0,32)$ mm olarak ölçüldü. Sağ göz ve sol göz OSKÇ ölçümleri bayan cinsiyette erkeklere göre daha düșük saptandı ve bu fark istatiksel olarak anlamliydı. ( $p=0,017$ ve $p=0,031$, strastyla).

Sonuç CCalıșmamızda Türk popülasyonunda sağlikl erişkinlerde OSKÇ ölçümleri sağ göz için 4.87 (0.41) mm sol göz için $4.86(0.32)$ mm olarak tespit edildi. Sağllklı bireylerde OSKÇ optimal referans değerlerinin belirlenebilmesi klinik pratikte kafa içi basınç artıșını öngörmede fayda sağlayacaktır.

Anahtar 


\section{INTRODUCTION}

Increased intracranial pressure (ICP) is one of the common conditions in patients admitted to the emergency service, and close clinical follow-up is often required for these patients. ${ }^{1-3}$ In addition, early and accurate diagnosis is of great importance in preventing possible complications and determining treatment strategies in these patients. ${ }^{4-6}$ ICP can be measured with tools that can be placed intraparenchymal and intraventricular. Although ICP can be measured directly with these tools, there are dangerous complications of it such as bleeding and infection. Moreover, they are not cost-effective, require intensive care conditions and are therefore preferred in selected patients. ${ }^{4,5,7,8}$

The optic nerve sheath can be described as a continuation of the intracranial dura surrounding the subarachnoid space. ${ }^{9}$ Changes occurred in ICP are also reflected in the optic nerve sheath via subarachnoid fluid. ${ }^{9,10}$ The optic nerve sheath diameter (ONSD), which can also be measured ultrasonographically, has taken its place as a non-invasive method used to predict ICP. Being easily applicable, inexpensive, repeatable and non-interventional procedure is one of the reasons why ultrasonography is preferred in the emergency service. ${ }^{11,12}$ Although the expansion in the optic nerve sheath can be visualized with increased intracranial pressure, an optimal ONSD value has not yet been reached in the representation of increase in ICP. Moreover, potential factors such as genetic structure and racial differences that may affect the optic nerve sheath have not been fully investigated due to the lack of studies performed on this subject. In the light of current information, there is no study conducted on ONSD on normal healthy volunteers in Turkish population in the literature. In this study, it was aimed to investigate how the normal values of ONSD are distributed in normal healthy volunteers in Turkish population.

\section{MATERIALS and METHODS}

This descriptive cross sectional type design study was conducted in emergency service of a tertiary hospital between
November 15, 2019 and April 15, 2020. During the study, the principles of Helsinki Declaration were adhered to, and written informed consents of all participants were obtained. Approval was obtained by Bozok University Faculty of Medicine Ethics Committee before the study started (Ethics Committee date / number: 30.10.2019 / 2019-10244).

Healthy volunteers who were over 18 years of age and didn't have acute and chronic systemic disorders were enrolled in the study. Study individuals were composed of the relatives of the patients admitted to emergency service and university hospital staff volunteering to participate in the study. The individuals who were under the age of 18 , had a history of cardiovascular disease, had neurological problems, had endocrinological diseases such as hypertroidism, hypotroidism and diabetes mellitus, had immunological and rheumatological diseases, had ocular disorder (vasculitis, tumor, glaucoma etc.) affecting the optic nerve and intraocular pressure, and used drugs affecting ICP and intraocular pressure were excluded from the study.

Heights, weights, ages and genders of the subjects accepted to the study were recorded. Then, ONSD measurements of the patients were performed ultrasonographically. HM70A with Plus ultrasound system (Samsung Medison Co., Ltd., Seoul, Korea) and 7-16 Mhz linear probe were used for the ultrasonographic examination. The subjects were placed on a stretcher in a supine position with a comfortable head. The eye socket was filled with a water-soluble and conductive gel when eyes were closed. The linear probe was placed on the eyeball filled with gel. The optic nerve was detected $3 \mathrm{~mm}$ behind the optical disc displayed behind the eyeball. Measurements were performed using an electronic caliper from this line. Optical nerve arachnoid differentiation was determined on ultrasonographic imaging (Figure 1). Measurements were realized by 4 emergency medicine specialists. Three measurements were taken for each eye and the mean of these measurements was recorded. 
Statistical analysis: Statistical analyzes were performed using IBM SPSS statistics version 22 software. The suitability of variables to normal distribution was examined with Kolmogorov-Smirnov test. Descriptive analyzes were given using the median and interquartile ranges for non-normally distributed variables. Comparison of independent variables that did not show normal distribution was made using Man-Whitney $U$ test. Correlation coefficients and statistical significance were calculated for the associations between non-normally distributed variables using Spearman test. P-values below 0.05 were considered statistically significant.

Table 1. Demographic characteristics and ONSD measurements of healthy subjects.

\begin{tabular}{|c|c|c|}
\hline \multicolumn{2}{|l|}{ Study Group } & $\mathrm{n}=160$ \\
\hline \multicolumn{3}{|c|}{ Gender, n (\%) : } \\
\hline & Male & $74(46.2)$ \\
\hline & Female & $86(53.8)$ \\
\hline \multicolumn{2}{|l|}{ Age } & $35(11)$ \\
\hline \multicolumn{2}{|l|}{ Height, (m) } & $1.68(0.1)$ \\
\hline \multicolumn{2}{|l|}{ Weight, (kg) } & $75(15)$ \\
\hline \multicolumn{2}{|l|}{ BMI, (kg/m2) } & $25.8(3.97)$ \\
\hline \multicolumn{2}{|c|}{ R-ONSD, mm } & $4.87(0.41)$ \\
\hline \multicolumn{2}{|c|}{ L-ONSD, mm } & $4.86(0.32)$ \\
\hline \multicolumn{3}{|c|}{$\begin{array}{l}\text { BMI: Body mass index, R-ONSD: Right eye optic nerve sheath } \\
\text { diameter, L-ONSD: Left eye optic nerve sheath diameter, Data } \\
\text { were expressed as n (\%) and median (interquartile range). }\end{array}$} \\
\hline
\end{tabular}

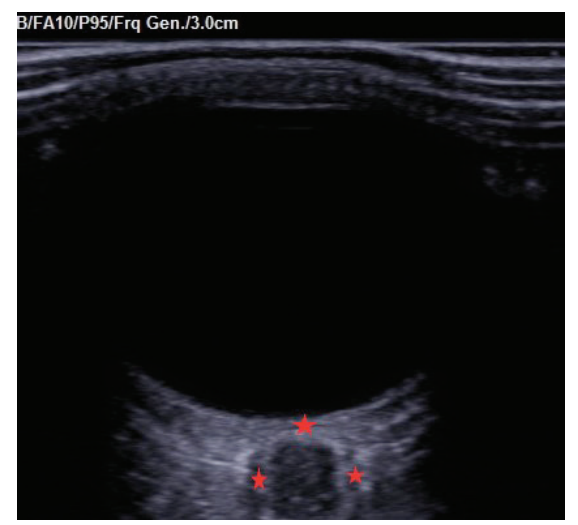

Figure 1: Ultrasonographic view of the optic nerve sheath diameter of a 25-year-old young individual

\section{RESULTS}

The average age of the subjects participating in the study was 35 (11), and 74 were male (46.2\%) and 86 (53.8\%) were female of them. Mean ONSD values of the subjects were measured as $4.87(0.41) \mathrm{mm}$ (median, IQR) for the right eye and $4.86(0.32) \mathrm{mm}$ for the left eye. The demographic data of the patients were shown in . Right eye and left eye ONSD measurements were lower in female gender than men, and this difference was statistically significant $(\mathrm{p}=0.017$ and $\mathrm{p}=0.031$, respectively) (Table 2$)$ (Figure 2 ).

\begin{tabular}{|c|c|c|c|}
\hline \multirow[t]{2}{*}{ ONSD, mm } & \multicolumn{2}{|c|}{ Between gender } & $\mathrm{p}$-value \\
\hline & Male & Female & \\
\hline Right eye & $4.92(0.3)$ & $4.81(0.54)$ & 0.017 \\
\hline \multirow[t]{3}{*}{ Left eye } & $4.89(0.2)$ & $4.81(0.49)$ & 0.031 \\
\hline & \multicolumn{2}{|c|}{ Between right/left eye } & \\
\hline & Right eye & Left eye & \\
\hline ONSD,mm & $4.87(0.41)$ & $4.86(0.32)$ & 0.636 \\
\hline \multicolumn{4}{|c|}{$\begin{array}{l}\text { ONSD: Optic nerve sheath diameter, Data were expressed as } \\
\text { median (interquartile range) }\end{array}$} \\
\hline
\end{tabular}

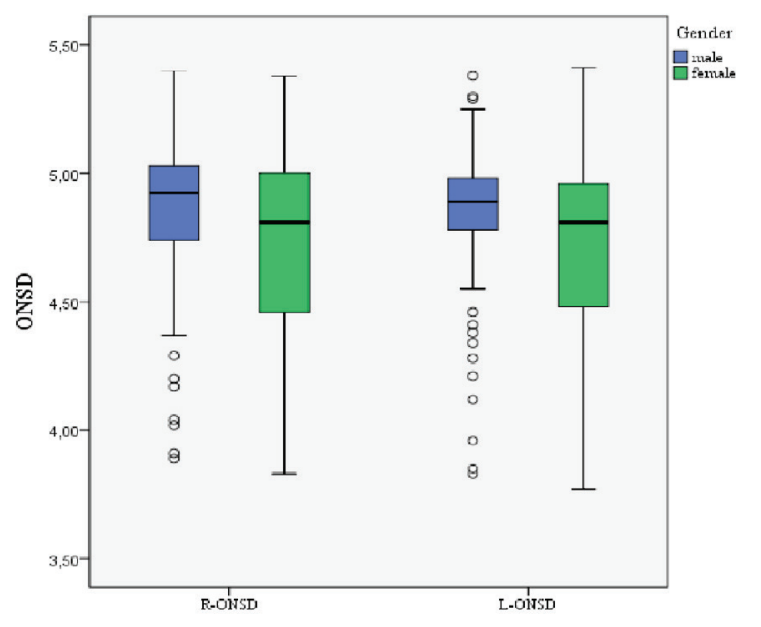

Figure 2: Box plot of the ONSD of different genders according to right and left eye.

The association between the patients' mean ONSD values and age, height, weight and BMI values were examined. No association was found between ONSD values of both 
right and left eyes, and age, height, weight and BMI values (Table 3).

\begin{tabular}{|c|c|c|}
\hline & p-value & r-value \\
\hline \multicolumn{3}{|l|}{ Right eye } \\
\hline Weight, (kg) & 0.301 & 0.082 \\
\hline Height, (m) & 0.238 & 0.094 \\
\hline BMI, (kg/m2) & 0.592 & 0.043 \\
\hline Age & 0.490 & 0.055 \\
\hline \multicolumn{3}{|l|}{ Left eye } \\
\hline Weight, (kg) & 0.299 & 0.083 \\
\hline Height, (m) & 0.339 & 0.076 \\
\hline BMI, (kg/m2) & 0.514 & 0.052 \\
\hline Age & 0.506 & 0.053 \\
\hline
\end{tabular}

\section{DISCUSSION}

In this study, the normal ranges of ONSD values in healthy individuals in Turkish population were investigated. The main findings of this study can be summarized as follows. 1) ONSD value in healthy volunteers was found to be 4.87 (0.41) for the right eye and $4.86(0.32) \mathrm{mm}$ for the left eye. 2) No statistically significant association was detected between ONSD values and height, weight, BMI and age. 3) ONSD values were observed lower in female gender.

In the studies performed so far, ONSD reference range has differed in healthy volunteers. In the study performed on Chinese healthy volunteers by Chen et al., they reported mean ONSD value as $5.1 \pm 0.5 \mathrm{~mm} \cdot{ }^{13}$ Goeres et al. found the mean of ONSD to be $3.68 \pm 0.36 \mathrm{~mm}$ in their study conducted on 120 healthy volunteers. ${ }^{14}$ In the study realized on 101 healthy volunteers of Bangladesh origin by Maude et al., the mean ONSD value was $4.41(4.24-4.83) \mathrm{mm}^{15}$ Bauerle et al. observed the mean ONSD value as $5.4 \pm 0.6$ $\mathrm{mm}$ in their study performed on 40 healthy volunteers in Germany. ${ }^{16}$ In our study, although the mean ONSD values were close to the values in these two studies ${ }^{13,15}$ performed, they were less than the average value found by Chen et al. ${ }^{13}$, but more than the mean value reported by Maude et al. ${ }^{15}$ These differences in ONSD values may be due to the differences in ethnic origin or ultrasonographic measurement techniques. Sargsyan et al. argued that it is not correct to measure only the 'black stripe' behind the globe without visualizing the differentiation of the optic nerve and arachnoid in ONSD measurement in their study. ${ }^{17}$ Goeres et al. reported that they took the 'black stripe' as a basis in their measurements. Although there is no definitive judgment, measurement methods may also have an impact on the lower ONSD values observed by Goeres et al. ${ }^{14}$ Optic nerve and arachnoid differentiation were taken into consideration in ONSD measurement in our study.

Chen et al. presented that there was no significant linear association between ONSD-age and ONSD-weight. ${ }^{13}$ They also found a statistically significant correlation between ONSD and height but detected that the correlation coefficient was too low. They therefore argued that this association should be considered independent of clinical interpretation. Goeres et al. revealed that there was an association between ONSD and gender, but reported that there was no association between age, weight or height and ONSD. ${ }^{14}$ ONSD values were lower in female patients than in men in their study. Bauerle et al. stated that there was no correlation between ONSD and age, BMI and gender. ${ }^{16}$ Any correlation between ONSD and age, height, weight and BMI was not found in our study. However, in accordance with the results of Goeres et al. ${ }^{14}$, ONSD values were observed lower in female individuals than in men in our study. The difference in ONSD values between women and men may indicate that different threshold values are needed to predict ICP increase. Also, there was no difference between the right and left eyes in terms of ONSD measurement in our study. This may mean that a single eye measurement is sufficient to predict ICP increase.

Limitation: There were some limitations in this study. Firstly, direct measurement methods were not used for ICP estimation of the subjects. According to medical his- 
tories and physical examination findings of the subjects, it was concluded that their ICPs were normal. The study was conducted only on adult subjects with BMIs below $30 \mathrm{~kg} /$ $\mathrm{m} 2$. Therefore, our study cannot predict the mean ONSD values of the obese and pediatric age groups. New studies are needed to clarify this issue.

Conclusion: Predicting ICP is critical in many patients admitted to the emergency service. It was found ONSD value as $4.87(0.41)$ for the right eye and $4.86(0.32) \mathrm{mm}$ for the left eye in healthy individuals in Turkish population in our study. Secondly, there was no association between ONSD and age, height, weight and BMI, but ONSD values were lower in female subjects than in men. Determination of ONSD optimal reference values in healthy individuals will benefit in predicting ICP increase in clinical practice. However, larger studies on healthy volunteers to define ONSD normal values are needed.

This study was approved by Bozok University Faculty of Medicine Ethics Committee (Ethics Committee date /

number: 30.10.2019 / 2019-10-244). 
Sakarya Med J 2021;11(1):85-90

\section{References}

1. Çökük A, Kozacı N, Ay MO, Açıkalın A, Seviner M, Satar S. Acil Servise Başvuran Kafa Travması Olgularının Değerlendirilmesi. Cukurova Medical Journal. 2013;38(1):63-71.

2. Dölen D, Sabanci PA. Kafa Travmasında Beyin Ödemi ve İntrakranyal Basınç Değişimleri. Türk Nöroşir Derg. 2020;30(2):187-193.

3. Kimberly HH, Shah S, Marill K, Noble V. Correlation of optic nerve sheath diameter with direct measurement of intracranial pressure. Acad Emerg Med. 2008;15(2):201-204.

4. Emmez ÖH, Egemen E. Kafa içi basınç artışı tedavisinde pratik yaklaşımlar. Yoğun Bakım Derg. 2010; 9(2):77-84.

5. Harary $M$, Dolmans $R G$, Gormley WB. Intracranial pressure monitoring-review and avenues for development. Sensors. 2018;18(2):465.

6. Changa AR, Czeisler BM, Lord AS. Management of Elevated Intracranial Pressure: a Review. Curr Neurol Neurosci Rep 2019;19(12):99.

7. Chesnut RM, Temkin N, Carney N, Dikmen S, Rondina C, Videtta W, et al. A trial of intracranial-pressure monitoring in traumatic brain injury. N Engl J Med. 2012;367(26):24712481.

8. Aiolfi A, Benjamin E, Khor D, Inaba K, Lam L, Demetriades D. Brain trauma foundation guidelines for intracranial pressure monitoring: Compliance and effect on outcome. World J Surg. 2017;41(6):1543-1549.

9. Hansen $H$, Helmke $K$. The subarachnoid space surrounding the optic nerves. An ultrasound study of the optic nerve sheath. Surg Radiol Anat. 1996;18(4):323-338.

10. Komut E, Kozacı N, Sönmez BM, Yılmaz F, Komut S, Ylldirım ZN, et al. Bedside sonographic measurement of optic nerve sheath diameter as a predictor of intracranial pressure in ED. Am J Emerg Med. 2016;34(6):963-967.
11. Rajajee V, Vanaman M, Fletcher JJ, Jacobs TL. Optic nerve ultrasound for the detection of raised intracranial pressure. Neurocrit Care. 2011;15(3):506-515.

12. Robba C, Santori G, Czosnyka M, Corradi F, Bragazzi N, Padayachy L, et al. Optic nerve sheath diameter measured sonographically as non-invasive estimator of intracranial pressure: a systematic review and meta-analysis. Intensive Care Med. 2018;44(8):1284-1294.

13. Chen H, Ding G-S, Zhao Y-C, Yu R-G, Zhou J-X. Ultrasound measurement of optic nerve diameter and optic nerve sheath diameter in healthy Chinese adults. BMC Neurol. 2015; 15(1):106

14. Goeres P, Zeiler FA, Unger B, Karakitsos D, Gillman LM. Ultrasound assessment of optic nerve sheath diameter in healthy volunteers. J Crit Care. 2016;31(1):168-171.

15. Maude RR, Hossain MA, Hassan MU, Osbourne S, Sayeed KLA, Karim MR, et al. Transorbital sonographic evaluation of normal optic nerve sheath diameter in healthy volunteers in Bangladesh. PloS one. 2013;8(12):e81013.

16. Bäuerle J, Lochner P, Kaps M, Nedelmann M. Intra-and interobsever reliability of sonographic assessment of the optic nerve sheath diameter in healthy adults. J Neuroimaging. 2012;22(1):42-45.

17. Sargsyan A, Blaivas M, Geeraerts T, Karakitsos D. Ocular ultrasound in the intensive care unit. Lumb P,Karakitsos D. Critical Care Ultrasound. Vol.1. Philadelphia, Elsevier Saunders. 2014. p. 45-50. 